\title{
Mutually Exclusive Expression of Alternatively Spliced FMRFamide Transcripts in Identified Neuronal Systems of the Snail Lymnaea
}

\author{
Kerris Bright, Elaine Kellett, Susan E. Saunders, Matthew Brierley, Julian F. Burke, and Paul R. Benjamin \\ Sussex Centre for Neuroscience, School of Biological Sciences, University of Sussex, Brighton BN1 9QG, United \\ Kingdom
}

\begin{abstract}
The FMRFamide gene of the snail Lymnaea encodes tetrapeptides (FMRFamide/FLRFamide) and heptapeptides (GDPFLRFamide/SDPFLRFamide) on separate exons. In situ hybridization probes specific to these exons were used to map the expression of the two exons in identified neuronal systems of the CNS. Analysis of more than 200 preparations showed that cytoplasmic expression of mRNA was exclusively of one type, with individual neurons expressing either the tetrapeptide or heptapeptide exon. Of the $\sim 340$ neurons expressing the two exons, the majority $(80 \%)$ expressed the tetrapeptide exon. The tetrapeptide exon was more widespread, occurring in neurons from all 11 ganglia of the CNS. The heptapeptide was mainly confined to two ganglia (visceral and right parietal), with a small number of cells in three other ganglia. Mapping studles comblned with dye marking of identified neurons showed the presence of the tetrapeptide exon in several behaviorally important networks: heart motoneurons, whole body withdrawal response motoneurons, and probably penis motoneurons as well as giant identified neurons (LP1, RPD1). The heptapeptides were prominent in two main clusters of cells (Bgp and Fgp) together with a smaller number of tetrapeptide-expressing cells.
\end{abstract}

[Key words: neuropeptide, mollusk, heart, in situ hybridization]

All the FMRFamide-encoding genes isolated to date show evidence of regulation by RNA splicing (Schaefer et al., 1985; Nambu et al., 1988; Schneider and Taghert, 1988). In the case of the snail Lymnaea this results in the mutually exclusive expression of at least two distinct classes of FMRFamide-related peptides, the tetrapeptides FMRFamide and FLRFamide, and the heptapeptides SDPFLRFamide and GDPFLRFamide (Saunders et al., 1992). Peptides in these classes have a wide range of activities. For example, the FMRFamide-related peptides exhibit potent cardioexcitatory actions in several species of mollusk such as Lymnaea (Buckett et al., 1990a) and Helix (Price, 1986), and noncardiac muscle has also been shown to be susceptible to the action of these peptides, these include the gill muscles of Aplysia (Weiss et al., 1984) and the tentacle retractor muscle of Helix (Cottrell et al., 1983). Analysis of thesc physiological systems by conventional immunocytochemical

\footnotetext{
Received Nov. 16, 1992; accepted Dec. 17, 1992.

This work was supported by a grant from the SERC. We thank Annie Bacon for typing the manuscript.

Correspondence should be addressed to Professor P. R. Benjamin at the above address.

Copyright $(1993$ Society for Neuroscience $0270-6474 / 93 / 132719-11 \$ 05.00 / 0$
}

methods is made difficult since both classes of peptide react to the most commonly used antibody raised against a tetrapeptide, FMRFamide. Hence, it is difficult to determine whether the tetrapeptides or heptapeptides are being expressed in specific ganglia or single neurons. This is important as the pharmacological properties of the two classes of peptide are distinct and, certainly in some systems, probably work via different types of reccptor (Cottrcll and Davies, 1987). Knowledge of the different exon sequences making up the Lymnaea FMRFamide gene enables the construction of specific probes for in situ hybridization (Linacre et al., 1990; Saunders et al., 1991, 1992). Hence, we can now unambiguously determine which class of peptide is expressed in various ganglia and individual neurons of the CNS. The data shown here suggest that the majority of cells that stain positively with an antibody raised against FMRFamide (Schot and Boer, 1982) express the FMRFamide gene and contain the FMRFamide-encoding exon as mRNA in the cytoplasm to the exclusion of the heptapeptide exon. In contrast, cells that express the heptapeptide exon are found clustered in a minority of the ganglia in a completely distinct set of neurons. Combining in situ analysis with mapping of identified neurons, including intracellular dye marking, has revealed the details of expression in several previously defined neural networks of considerable behavioral importance.

\section{Materials and Methods}

Materials. Restriction enzymes were purchased from Anglian Biotechnology or Boehringer Mannheim. Klenow for random priming, and nick translation kits were purchased from Amersham International. The $\alpha^{32} \mathrm{P}$ dCTP was purchased from ICN Radiochemicals; $\alpha^{35}$ S-dATP, Hybond$\mathrm{N}$, and Autoradiographic LM-1 emulsion were purchased from Amersham. X-ray film was purchased from Kodak.

Molecular procedures. Standard procedures were carried out as described by Sambrook et al. (1989).

DNA hybridization probes. Two DNA sequences were used: tetrapeptide probe, the cDNA sequence in the plasmid pD3 (described in Linacre et al., 1990) encoding nine copies of FMRFamide plus the additional putative peptide EFLRIamide, and a heptapeptide probe, a cDNA sequence (SM1) encoding four tandem copies of GDPFLRFamide, corresponding to nucleotides 161-284 of Saunders et al. (1991). The fragment was cut out of pSM1, gel purified, and self ligated to create a larger template.

RNA extraction and Northern analysis. RNA was extracted, denatured, and transferred as described previously (Linacre et al., 1990). The plasmid insert, $\mathrm{pD} 3$, was labeled with $\alpha^{32} \mathrm{P}$-dCTP using the random priming method and put through a Sephadex G50 column to remove unincorporated nucleotides. The filter was hybridized with the probe overnight at $65^{\circ} \mathrm{C}$ and washed at a final stringency of $6 \times$ saline-sodium citrate, $0.1 \%$ SDS at $68^{\circ} \mathrm{C}$ for $20 \mathrm{~min}$ and exposed to film for $3 \mathrm{~d}$. To remove the probe, the filter was then washed $\left(0.1 \% \mathrm{SDS}, 68^{\circ} \mathrm{C}, 20 \mathrm{~min}\right)$. A film was placed on the filter overnight and developed to determine 
A

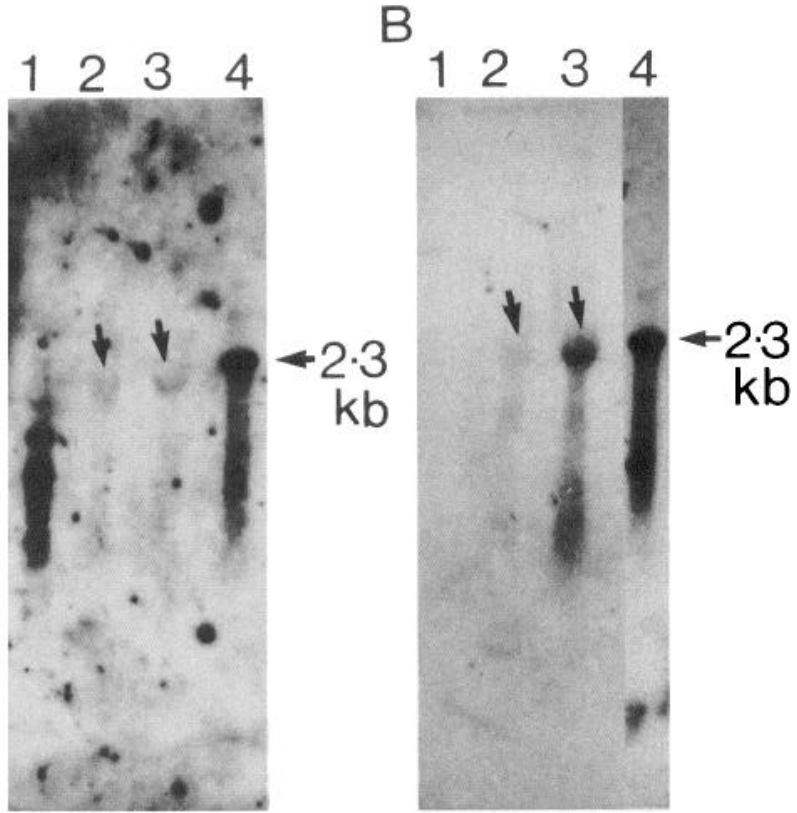

Figure 1. Northern analysis of FMRFamide gene transcripts. The visceral and right parietal ganglia were dissected from $50 \mathrm{CNS}$, and total RNA was extracted and run (track $3, A$ and $B$ ) as described in Materials and Methods. RNA from the remaining ganglia was extracted and also run (track 2, $A$ and $B$ ). After transfer to Hybond-N (Amersham), the filter was first hybridized with radioactively labeled pD3 containing FMRFamide sequences and exposed to $\mathrm{x}$-ray film $(A)$. The hybridization probe was then removed and rehybridized with SM1 encoding the heptapeptides $(B)$. Bacteriophage $\lambda$ HindIII/EcoRI markers are shown in tracks $I$ and 4 . The arrows indicate the position of hybridizing RNAs.

that there was no signal remaining. The filter was reprobed using SMI to hybridize to GDPFLRFamide RNA and exposed for $3 \mathrm{~d}$.

In situ hybridization. The two DNA probes outlined above were labeled with $\alpha^{35}$ S-dATP, and hybridized to sections exactly as described by Saunders et al. (1992) and in more detail by Burke et al. (1992). The specific activities of the probes ranged from $1 \times 10^{8}$ to $3 \times 10^{8} \mathrm{dpm}$ $\mu \mathrm{g}^{-1}$, used at $10 \mathrm{ng}$ per slide.

Dye marking of identified neurons. Identified neurons in the isolated Lymnaea CNS were filled with the fluorescent dye Lucifer yellow $\mathrm{CH}$ by iontophoresis, using standard techniques (e.g., Elliott and Benjamin, 1985). This enabled neurons to be positively identified in serial sections, and photographed, prior to hybridization. Following dye injection, the CNS were maintained at $4^{\circ} \mathrm{C}$ in HEPES-buffered saline for up to $2 \mathrm{hr}$ (Benjamin and Winlow, 1981) prior to freezing. Fixation in paraformaldehyde vapor followed by wax embedding and sectioning were carried out using the protocol of Burke et al. (1992).

\section{Results}

\section{Northern analysis of transcripts}

Before commencing with in situ hybridization studies, it was useful to show that the hybridization probes were annealing to only a single RNA species. This was done by the use of Northern blot analysis of the RNA from different ganglia (Fig. 1). Probes specific for FMRFamide (Fig. 1A) or GDPFLRFamide (Fig. 1B) were used. If alternative splicing and differential expression do indeed take place, then mRNAs of different sizes would be detected. The CNS was divided into two groups: visceral and right parietal ganglia versus the rest of the CNS. This was done as the initial in situ hybridization data showed that FMRFamide and GDPFLRFamide were expressed in different neurons and that FMRFamide was shown to be present in cells of all ganglia, whereas the majority of the GDP/SDPFLRFamide-expressing

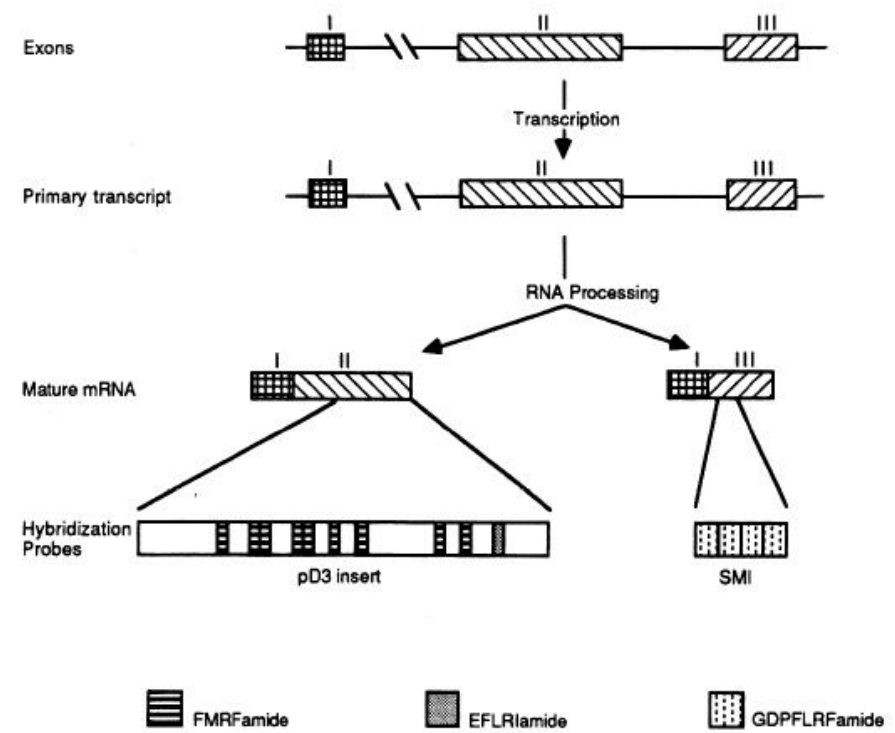

Figure 2. Origin of DNA probes used for in situ hybridization. The alternatively spliced transcripts result from a common RNA precursor, the primary transcript. This is spliced in two different ways to give two mature mRNAs. In situ hybridization probes pD3 (972 nucleotides) and SM1 (123 nucleotides) correspond to the two different transcripts; the lower portion of the figure indicates the peptides encoded by these probes.

cells were found in the visceral and right parietal ganglia. On hybridizing the Northern blot with the probe specific for FMRFamide, it can be seen (Fig. $1 \mathrm{~A}$ ) that, as expected, a band of 1.7 kilobases $(\mathrm{kb})$ was detected in both lanes, whereas the GDPFLRFamide specific probe predominantly hybridized to a slightly larger band of $1.8 \mathrm{~kb}$ in the visceral/right parietal track. This suggests that the two probes each hybridize to only a single species of RNA and that there is little, if any, cross-hybridization between them.

\section{In situ hybridization probes}

Previous molecular data (Saunders et al., 1992) had shown that the FMRFamide peptides are encoded by a single gene, the primary transcript being spliced in a cell-specific manner according to the model shown in Figure 2. Cloned DNA sequences corresponding to nucleotides $380-1352$ (pD3 of Linacre et al., 1990) are specific for transcripts expressing peptides encoded by the FMRFamide exon, and sequences corresponding to nucleotides 161-284 (SM1) of Saunders et al. (1991) are specific for the heptapeptide GDP/SDPFLRFamide exon. For in situ hybridization these cloned sequences were purified from agarose gels, labeled with $\alpha^{35}$ S-dATP using a nick translation procedure, denatured, and hybridized to $7 \mu \mathrm{m}$ sections from the Lymnaea brain. The hybridization signal was sensitive to RNase A, showing that hybridization was specific to mRNA (not shown).

\section{Comparison of tetrapeptide and heptapeptide expression}

Summary maps based upon in situ hybridization experiments with over 200 brains are shown in Figure 3. As predicted by the proposed alternative splicing model, the individual cells are positive for either the tetrapeptide exon or the heptapeptide exon but never both. The relative proportion of cells expressing each class of transcript can be easily seen, the FMRFamide exon being present in more cells $(80 \%$ of total cells expressing the two exons) than the GDP/SDPFLRFamide exon. 
A DORSAL VIEW

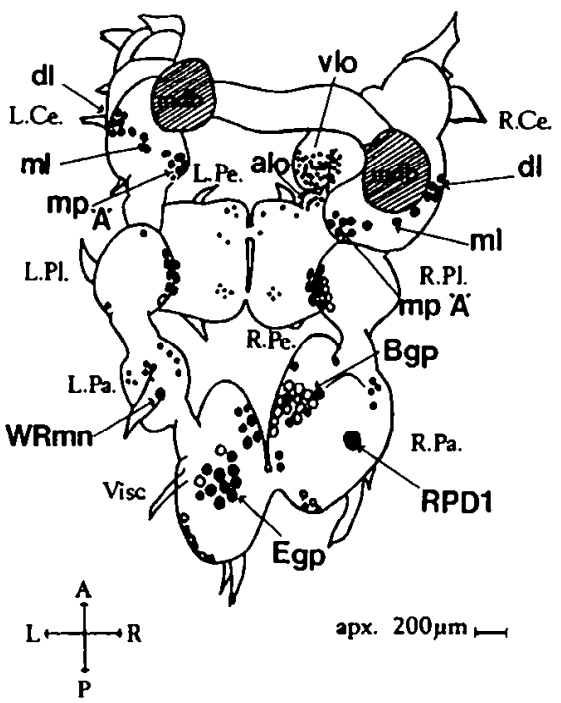

LEFT SIDE VIEW
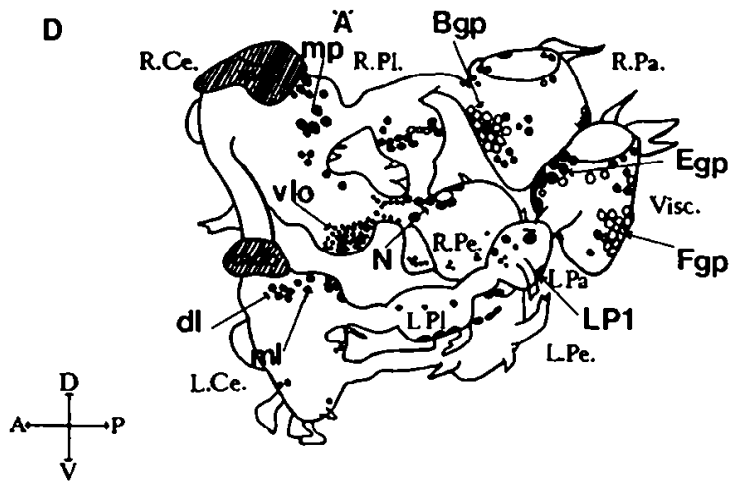

$\mathbf{B}$

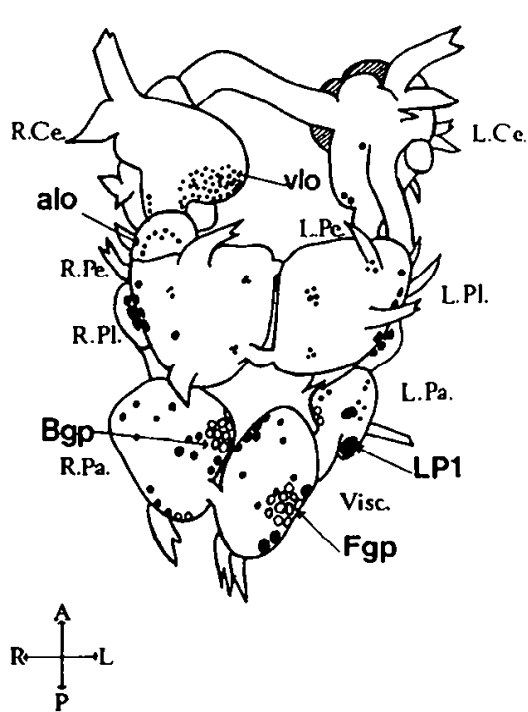

$R \stackrel{\left.\right|_{\mathbf{P}} ^{A}}{\mathrm{~L}} \mathrm{~L}$

VENTRAL VIEW

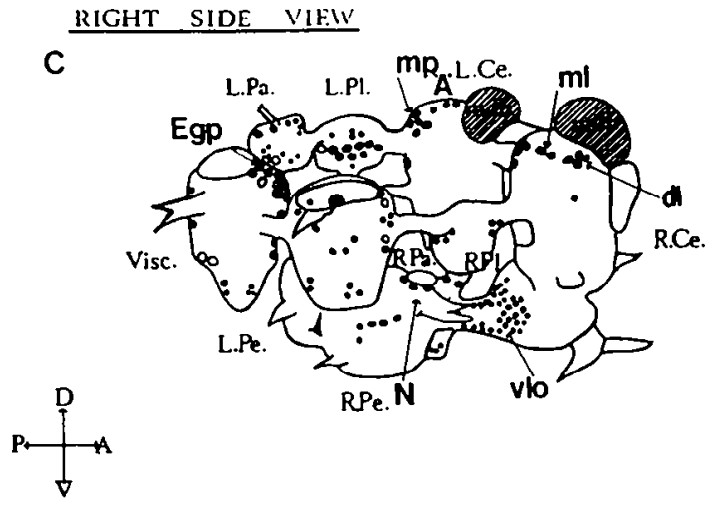

Figure 3. Summary maps showing the localization of neurons expressing the FMRFamide tetrapeptide cxon (solid circles) and heptapeptide exon (open circles) in the Lymnaea CNS; 20 sets of consecutive sections that were hybridized with either tetrapeptide or heptapeptide exon-specific probes were analyzed and the positions of expressing cells marked onto a perspex model of the Lymnaea CNS (Benjamin et al., 1980). The model was then drawn from four different views, dorsal $(A)$, ventral $(B)$, right side $(C)$, and left side $(D)$. Ganglia: $L$.Ce., left cerebral ganglion; $L . P a$., left parietal ganglion; $L . P e$., left pedal ganglion; $L . P l$., left pleural ganglion; $R . C$., right cerebral ganglion; $R$.Pa., right parietal ganglion; $R . P e$., right pedal ganglion; R.Pl., right pleural ganglion; Visc., visceral ganglion. Lobes: alo, anterior lobe; mdb, mediodorsal body; vlo, ventral lobe. Neuron groups or single identified cells: Bgp, B group; $d l$, dorsal-lateral group; Egp, E group; Fgp, F group; $L P I$, left parietal 1; ml, medial-lateral group; $\mathrm{mp}$ 'A', medial posterior group, A cluster motoneurons; $N, \mathrm{~N}$ cells; $W R m n$, left parietal ganglion withdrawal response motoneuron.

General features of distribution of tetrapeptide- and heptapeptide-encoding exon-expressing neurons in the CNS of Lymnaea

The most striking feature of the expression of the tetrapeptide exon within the CNS is its wide distribution and variation in expression levels. A maximum of 284 cells expressed this exon, and they were present in all 11 ganglia, in cells ranging in cell body diameter from 10 to $140 \mu \mathrm{m}$. However, as can be seen from the data presented in Table 1, the distribution is far from uniform. For example, there are a considerable number of medium to large (40-140 $\mu \mathrm{m}$ diameter) expressing cells in the posterior ganglia, that is, the visceral, left, and right parietal (total $=90$ ). There are more cells in the cerebral and pedal ganglia $(n=152)$, but the majority of these cells are small (10-
$30 \mu \mathrm{m}$ diameter). The relatively large size of the cerebral and pedal ganglia compared with the parietal and visceral ganglia emphasizes the abundance of tetrapeptide exon-expressing cells in the latter. The pleural ganglia contain a large number of expressing cells $(n=38)$ in relation to the small size of the ganglia. The buccal ganglia are conspicuous in that they contain only four tetrapeptide exon-expressing cells.

The restricted distribution of the heptapeptide exon encoding GDP/SDPFLRFamide within the CNS is in contrast to that of the tetrapeptide exon. The heptapeptide exon is expressed in a maximum of 57 cells in only five ganglia. The majority of expressing cells are located within the visceral and right parietal, with a small number in the pleural and left parietal ganglia (Table 2). Furthermore, where expression does occur the positive neurons are generally situated in close proximity to, or among, tetrapeptide-expressing cells (Fig. 3). 
Table 1. The position, size (maximum cell body diameter), number (maximum), and relative signal strength of tetrapeptide exon-expressing neurons within the Lymnaea CNS

\begin{tabular}{|c|c|c|c|c|}
\hline Ganglion & Position & $\begin{array}{l}\text { Max no. } \\
\text { of cells } \\
(L+R)\end{array}$ & Size $(\mu \mathrm{m})$ & Signal strength \\
\hline \multirow[t]{3}{*}{ Buccal } & Anterior symmetrical pair & 2 & $20-30$ & $+t$ \\
\hline & Posterior symmetrical pair & $\underline{2}$ & $40-50$ & +++ \\
\hline & Total (left and right) & 4 & & \\
\hline \multirow[t]{9}{*}{ Cerebral } & Dorsal lobe & & & \\
\hline & Dorsal-lateral group & 16 & $20-40$ & ++++ \\
\hline & Medial-lateral group & 8 & $20-40$ & ++ \\
\hline & Medial-posterior grp (A cluster-WRmn) & 16 & $60-100$ & + \\
\hline & Scattered & 8 & $20-40$ & +++ \\
\hline & Ventral lobe & & & \\
\hline & Left & 4 & $30-50$ & +++ \\
\hline & Right & 60 & $15-20$ & $+t+t$ \\
\hline & Total (left and right) & 112 & & \\
\hline \multirow[t]{7}{*}{ Pedal } & Ventral symmetrical pair & 2 & $20-30$ & $++t$ \\
\hline & Near pleural connective, & & & \\
\hline & Cerebral connective (N-cells) & 12 & $30-50$ & +++ \\
\hline & Scattered small clusters & 16 & $10-30$ & $++t$ \\
\hline & Lateral symmetrical pair & 2 & $40-60$ & ++ \\
\hline & Right anterior lobe (I cluster)' & $\underline{8}$ & $20-30$ & $t+t+$ \\
\hline & Total (left and right) & 40 & & \\
\hline \multirow[t]{4}{*}{ Pleural } & Medial-ventral group & 10 & $20-40$ & +++ \\
\hline & Medial group & 16 & $20-40$ & +++ \\
\hline & Scattered & 12 & $15-20$ & ++ \\
\hline & Total (left and right) & 38 & & \\
\hline \multirow[t]{6}{*}{ Left Parietal } & Dorsal cluster & 6 & $40-60$ & ++ \\
\hline & Dorsal cell (WRmn) & 1 & $60-90$ & +++ \\
\hline & Ventral-lateral cell & 1 & $60-90$ & ++ \\
\hline & Ventral-posterior (LPI) & 1 & $130-140$ & ++ \\
\hline & Scattered & 16 & $15-40$ & \\
\hline & Total & 25 & & \\
\hline \multirow[t]{7}{*}{ Right Parietal } & Dorsal surface (RPD1) & 1 & $120-130$ & $++t$ \\
\hline & Dorsal-lateral & 6 & $20-80$ & +++ \\
\hline & Dorsal-anterior (Bgp) & 6 & $40-80$ & +++ \\
\hline & Posterior & 8 & $20-80$ & +++ \\
\hline & Ventral-anterior & 4 & $40-80$ & +++ \\
\hline & Scattered & 10 & $20-60$ & +++ \\
\hline & Total & 35 & & \\
\hline \multirow[t]{6}{*}{ Visceral } & Dorsal (Egp) & 10 & $30-90$ & $+++t$ \\
\hline & Dorsal-anterior & 6 & $30-100$ & ++++ \\
\hline & Lateral-ventral (Fgp) & 6 & $40-100$ & +++ \\
\hline & Scattered & 8 & $20-60$ & +++ \\
\hline & Total & 30 & & \\
\hline & Total number of tetrapeptide-expressing cells & 284 & & \\
\hline
\end{tabular}

Parentheses indicate identified neurons; $L$, left; $R$, right; WRmn, withdrawal response motoneurons; $+\rightarrow+++++$, lowest to highest signal strength.

\section{Expression in individual ganglia and identified neurons}

Buccal ganglia. Two small (20-30 $\mu \mathrm{m}$ diameter) neurons consistently hybridized to the tetrapeptide exon (Table 1) and are located in the anterior region of the buccal ganglia close to the root of the buccal commissure. Occasionally, a second anterior cell could be observed on the left forming a pair of adjacent cells on one side only. A second pair of bilaterally symmetrical cells were also consistently found on the dorsal-posterior surface making a total of four tetrapeptide-expressing cells in the buccal ganglia (Table 1). None of these cells appear to correspond to previously identified cells of the feeding circuitry (Benjamin and Elliott, 1989). No signal was observed in any cell with the heptapeptide probe, indicating that the peptide is not expressed in the buccal ganglia.

Cerebral ganglia. No heptapeptide-expressing cells were observed in the cerebral ganglia, but four distinct bilaterally symmetrical clusters of positive cells expressing the tetrapeptide exon were observed, as well as a number of scattered cells. Three of these clusters occur in the dorsal lobes and one in the ventral 


\begin{tabular}{|c|c|c|c|c|}
\hline Ganglion & Position & $\begin{array}{l}\text { Number } \\
\text { of cells } \\
(\mathrm{L}+\mathrm{R})\end{array}$ & Sizc $(\mu \mathrm{m})$ & Signal strength \\
\hline Left pleural & Medial-posterior & 1 & $20-40$ & ++ \\
\hline \multirow[t]{2}{*}{ Right pleural } & Medial-posterior & 4 & $20-40$ & ++ \\
\hline & Total (lcft + right $)$ & 5 & & \\
\hline Left parietal & Posterior & 2 & $20-40$ & ++ \\
\hline \multirow[t]{5}{*}{ Right parietal } & Dorsal-anterior (Bgp) & 6 & $40-80$ & +++ \\
\hline & Ventral-anterior (Bgp) & 10 & $40-80$ & +++ \\
\hline & Lateral & 4 & $20-60$ & +++ \\
\hline & Scattered & 4 & $20-40$ & ++ \\
\hline & Total (left + right) & 26 & & \\
\hline \multirow[t]{4}{*}{ Visceral } & Lateral-ventral (Fgp) & 14 & $40-80$ & ++ \\
\hline & Anterior (Fgp) & 2 & $20-40$ & $+t+$ \\
\hline & Scattered cells & $\underline{10}$ & $20-100$ & + to +++ \\
\hline & Total & 26 & & \\
\hline \multicolumn{2}{|c|}{$\begin{array}{l}\text { Total number of heptapeptide-expressing cells } \\
\text { in the CNS }\end{array}$} & 57 & & \\
\hline
\end{tabular}

Parentheses indicate identified neurons. $L$, left; $R$, right. $+\cdots+++$, Lowest to highcst signal strength.

lobe. The dorsal lobe clusters are three distinct groups but form a continuous distribution stretching from the anterior-lateral part of the dorsal lobe to the posterior-medial surface. This distribution of all three groups within the left cerebral ganglion is shown in Figure $4 A$ and summarized for both cercbral ganglia in Figure 3. The more lightly expressing cells (as measured by signal strength), forming the medial-posterior group of cells (labeled $\mathrm{c}$ in Fig. $4 A$ ), appear to correspond to the cerebral $\mathrm{A}$ cluster, which contains motoneurons innervating the muscles that mediate the whole body withdrawal response (Benjamin et al., 1985; Ferguson and Benjamin, 199 la,b). This was confirmed by dye marking one of these cells from the posterior part of the cluster (probably a motoneuron of the dorsal longitudinal muscle (DLM; Ferguson and Benjamin, 199la) and showing that its cytoplasm expressed the tetrapeptide cxon (Fig. 5). The other two clusters do not appear to correspond to any other known cell types. A large cluster of 60-80 very small $(10-20 \mu \mathrm{m} \mathrm{di}$ ameter) expressing cells in the ventral lobe of the right cerebral ganglion is very striking and consistently exhibits a high density of silver grains above the cells (Fig. $4 B$ ). The ventral lobe of the left cerebral ganglion is less prominent than the right and contains very few cells expressing the tetrapeptide exon (Fig. 3D). Van Duivenboden (1984) showed that many of the cells in the ventral lobe of the right cerebral ganglion are probably penis motoneurons, and so it appears likely that the neural network controlling the penis utilizes FMRFamide as the predominant peptide. No cells in this region express the heptapeptide exon.

Pedal ganglia. Of the two alternatively spliced exons only the tetrapeptide exon is expressed in the pedal ganglia and its pattern appears to be symmetrical with the exception of the cells in the anterior lobe (there is no corresponding structure on the left side, Fig. $3 B$ ). Many of the FMRFamide cxon-expressing cells are relatively small (15-40 $\mu \mathrm{m}$ diameter) and occur in clusters of three to five cells distributed throughout the ganglia (Fig. 3). There are also two pairs of cells, one lateral pair and a second pair that lies close to the ventral pedal connective. These clusters and pairs do not appear to correspond to any previously identified cells (Slade et al., 1981). The dorsal surfaces of both ganglia contain a group of cells that are located in close proximity to the pedal-pleural and pedal-cerebral connectives (Fig. 4D). On the basis of position, and size, these cells appear to correspond to a cluster of whole body withdrawal response motoneurons, the N-cells (Benjamin et al., 1985; Ferguson and Benjamin, 1991 a). Another prominent group of tetrapeptide exon-expressing cclls is located deep within the anterior lobe of the right pedal ganglion (Fig. $4 C$ ). The right anterior lobe is situated at the lateral side, near the entrance of the cerebropedal connective and consists of a cluster of cells (diameter, $40-60 \mu \mathrm{m}$ ) called the I cluster (Slade et al., 1981). Some of the cells of this cluster ( $n$ $=25-35$ ) project to the penis nerve, suggesting a motoneuronal function (Van Duivenboden, 1984). The cells identified in this study are located deep within the anterior lobe and are relatively few in number $(n=8)$ and of small size (diameter, $20-40 \mu \mathrm{m})$. They can only form a small part of the I cluster, and until further detailed neurophysiology is carried out, their role in penis control can only be an initial suggestion.

Pleural ganglia. Cells that express the heptapeptide as well as cells that express the tetrapeptide exon in the cytoplasm are found in this pair of ganglia. The left and right pleural ganglia were found to contain a total of 38 ncurons that express the tetrapeptide exon, in sizes ranging from 15 to $40 \mu \mathrm{m}$ in diameter (Table 1, Fig. 3). Two bilaterally symmetrical clusters of medial and medial-ventral cells occur, as well as scattered cells on both sides. The position of the medial group raised the possibility that this group corresponded to the bilaterally symmetrical D cluster, identified cell groups described by Haydon and Winlow (1982) and Ferguson and Benjamin (1991a,b). However, dye marking of two randomly selected $\mathrm{D}$ cluster neurons with $\mathrm{Lu}$ cifer yellow showed the absence of tetrapeptide exon expression (not shown).

A much smaller number ( $n=5$ ) of heptapeptide-expressing cells are found in the plcural ganglia. The right ganglion contains four heptapeptide-expressing cells, whereas only one cell could be found on the left side (Fig. 3A). There is no overlap between the tetrapeptide and heptapeptide scts of expressing cells.

Left parietal ganglion. The left parietal ganglion contains a 

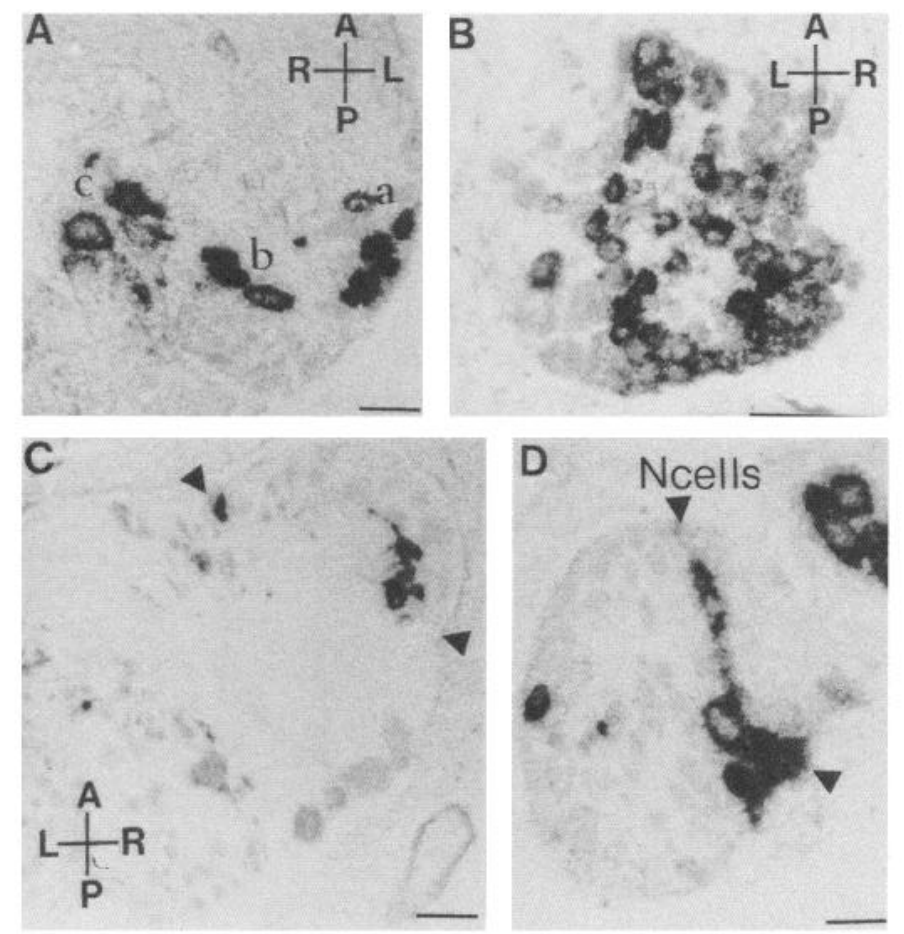

Figure 4. FMRFamide tetrapeptide-expressing neurons in the cerebral and pedal ganglia. $A$, Cells from the dorsal lobe of the cerebral ganglia. Three groups of cells are recognized: the dorsal-lateral $(a)$, medial-lateral $(b)$, and medial-posterior $(c)$ groups. The medial-posterior group probably corresponds to the cerebral A cluster of motoneurons (Ferguson and Benjamin, 1991a) involved in whole body withdrawal responses. $B$, Ventral lobe of the right cerebral ganglion, viewed under higher magnification, showing the cluster of small, heavily expressing cells. Neurons from this lobe are known to project to the penis nerve (Van Duivenboden, 1984), and so these cells may be involved with penis control. $C$, The anterior lobe (above arrowheads) of the right pedal ganglion showing small heavily expressing cells. These are probably cells of the I cluster, thought to be involved in penis control (Van Duivenboden, 1984). $D$, Heavily expressing cells close to the origin of the pedalpleural connective. These cells probably correspond to the N-cells of Ferguson and Benjamin (1991a) that are motoneurons of the whole body withdrawal system of Lymnaea. Scale bars, $100 \mu \mathrm{m}$.

large number of tetrapeptide exon-expressing cells $(n=25)$ relative to its small size (Table 1, Fig. 3). Only two heptapeptideexpressing neurons were found situated on the ventral surface in distinct locations compared with the tetrapeptide-expressing cells (Fig. $3 B$ ). Many of the tetrapeptide-expressing cells were scattered throughout the ganglion and were relatively small in size (15-40 $\mu \mathrm{m}$ in diameter).

Interestingly, two large cells expressed the tetrapeptide exon and appeared to correspond to previously identified neurons. The largest expressing cell $(\sim 140 \mu \mathrm{m})$ was located at the posterior edge of the ventral surface and is likely to be LP1 (left parietal 1) on the basis of positional and morphological characteristics (Benjamin and Ings, 1972; Winlow and Benjamin, 1976). LP1 was subsequently dye marked with Lucifer yellow $(n=3)$ and on all three occasions was consistently found to express the tetrapeptide exon (e.g., Fig. $6 A, B$ ). Application of the heptapeptide probe to the same cell on an alternate section showed the absence of heptapeptide expression (Fig. $6 \mathrm{C}$ ). The second large cell (70-90 $\mu \mathrm{m})$ occupied a dorsal location within the ganglion (Fig. $3 B$ ). On the basis of position and size, this cell appeared to correspond to an identified motoneuron forming part of the withdrawal response system (Benjamin et al., 1985; Ferguson and Benjamin, 1991a). Again, dye marking one of these cells with Lucifer yellow (Fig. $6 D$ ) confirmed the correct identification of this tetrapeptide-expressing neuron (Fig. $6 E, F$ ). A third large cell also expresses the tetrapeptide exon, but this cell has not been previously identified.

Right parietal ganglion. The right parietal ganglion contains a relatively large number of tetrapeptide exon-expressing cells $(n=35$; Table 1$)$ in a broad range of cell body sizes $(20-130$ $\mu$ m diameter) and slightly fewer $(n=24$; Table 2$)$ heptapeptideexpressing cells. The most prominent tetrapeptide-expressing cell was particularly large (130 $\mu$ m diameter), being located on the dorsal surface of the ganglion (Fig. $3 A$ ), and is likely to be the identified cell RPD1 (right parietal dorsal 1) (Benjamin and Winlow, 1981). No large heptapeptide-expressing neuron occurs in the same part of the ganglion. Confirmation of the identity was achieved by dye injecting four neurons. All four cells showed consistent cytoplasmic expression of the tetrapeptide exon (not shown).

The majority of the tetrapeptide-expressing cells were distributed throughout the ganglion: no particularly large groups of cells were apparent (Fig. 3). However, several fairly large cells (60-90 $\mu \mathrm{m}$ in diameter) occupying dorsal-anterior and ventralanterior positions could be observed. The anterior surface of the ganglion is occupied by the B group (Bgp) cells, an identified group of cells (15-18 neurons) that are characterized by their shared morphological and electrical properties (Benjamin and Winlow, 1981) and that have been shown on the basis of immunohistochemistry to contain FMRFamide-related peptides
Figure 5. FMRFamide tetrapeptide expression in an identified cerebral ganglion neuron of the cerebral "A" cluster ( $R C e M n$, right cerebral motoneuron). Cells from cluster are motoneurons of the whole body withdrawal response system (Ferguson and Benjamin, 1991a). A, Lucifer yellow-filled neuron. $B$, Weak expression of the tetrapeptide exon in the same neuron. $C$, Same cell but at higher magnification. Note the other adjacent " $A$ " cluster neurons also expressing the same exon. Scale bars, $100 \mu \mathrm{m}$.
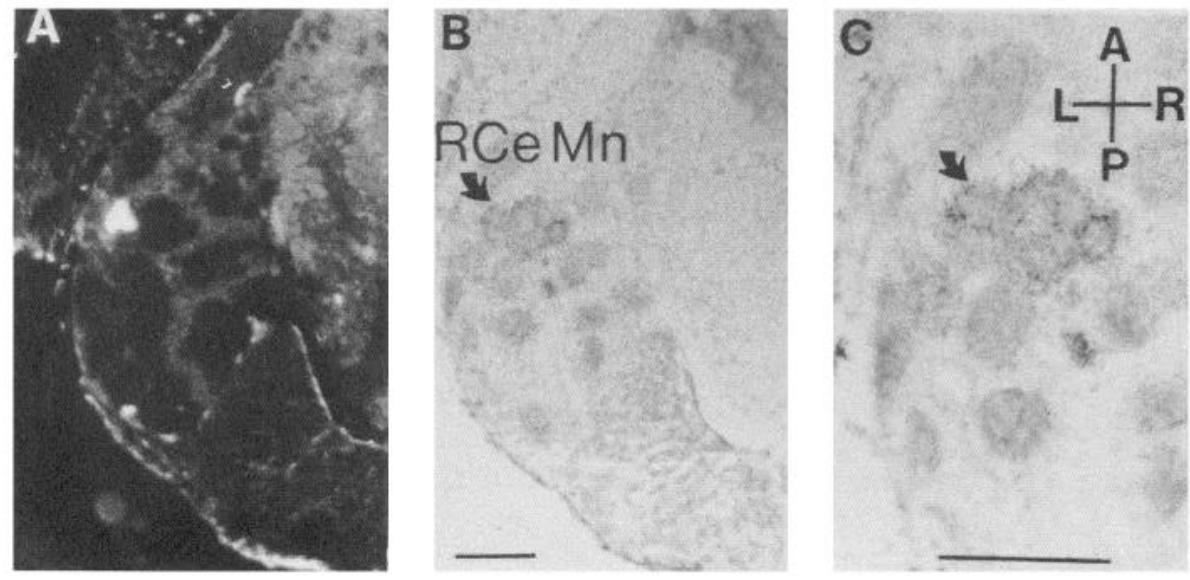

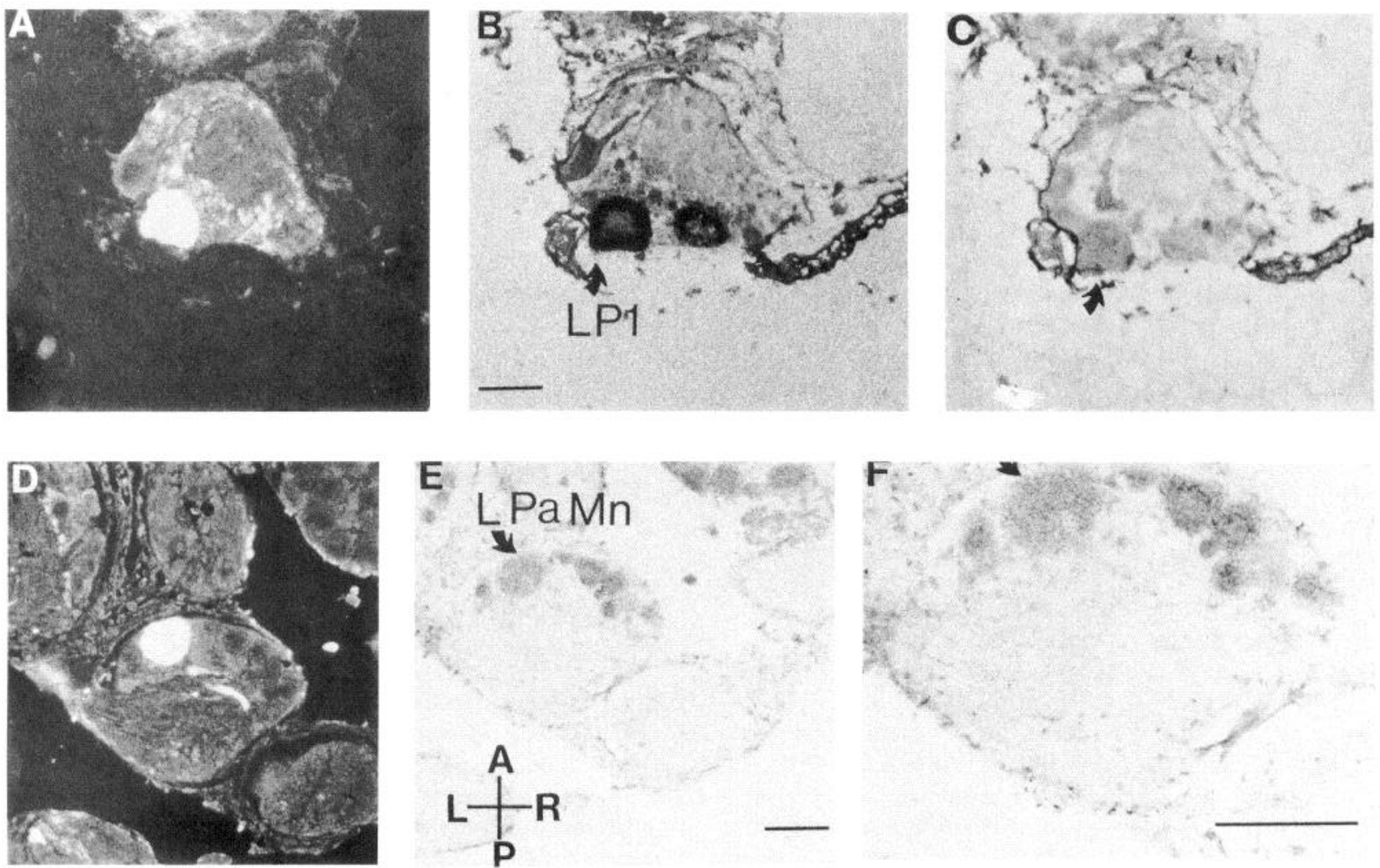

Figure 6. Left parietal ganglion identified neurons expressing the FMRFamide tetrapeptide exon. $A$, The identified giant neuron LP1 (left parietal 1) was filled with Lucifer yellow. $B$, It expressed the tetrapeptide exon but not the heptapeptide exon $(C$, arrowed $)$. $D$, The left parietal whole body withdrawal response motoneuron $(L P a M n)$, filled with Lucifer yellow, weakly expressed the tetrapeptide exon $(E)$, shown more clearly in the enlarged photomicrograph of $F$. Scale bars, $100 \mu \mathrm{m}$.

(Benjamin et al., 1988). The cells are pale-cream in color, and form a very tightly packed group on this surface (Benjamin and Winlow, 1981). The anterior cells identified by in situ hybridization are smaller and were scattered, unlike the Bgp cells in the living ganglion. They therefore cannot be the main groups of neurons forming the Bgp, but the more dorsal cells (dorsalanterior cells, $n=6$ ) are likely to be a subset of this cell type. Other positive tetrapeptide-expressing cells were visible in the dorsal-lateral and posterior positions (Fig. $3 A$ ) and other more scattered cells throughout the right parietal ganglion (Fig. 3).

The heptapeptide-expressing cells in the right parietal ganglia are fewer in number $(n=24)$, and the main group forms a tight group of cells $(n=16$, dorsal-anterior and ventral-anterior cells of Table 2) positioned just medial to the anterior tetrapeptide exon-expressing cells (Fig. $3 B$ ). The location, group size, and close proximity of these heptapeptide-expressing cells suggest that they encompass most of the Bgp cells (Benjamin and Winlow, 1981), with the tetrapeptide-expressing cells forming a more scattered subset of these cells (Fig. 3A,D). This was confiirmed by dye marking six of the large prominent Bgp cells. All of these expressed the heptapeptide exon but not the tetrapeptide exon (e.g., Fig. 7). Additional heptapeptide-expressing cells found in lateral locations, or in a more scattered distribution, do not appear to correspond to any previously identified cell groups.

Visceral ganglion. This ganglion, in relation to its size, contains a large number of tetrapeptide exon-expressing cells ( $n=$ 30 ; Table 1). These form two main groups together with a smaller number of heptapeptide-expressing cells (Fig. 3). The first group of tetrapeptide-expressing cells is located anteriorly and extends from the dorsal surface to more ventrally located positions (Fig. 3A,B) (dorsal and dorsal-anterior cells, Table 1). The second group of cells is more lateral and posterior in location (Fig. $3 A, D$; lateral-ventral cells of Table 1). On the basis of position and cell body diameters these cells probably correspond to members of the electrophysiologically mapped E group (Egp) (Benjamin et al., 1985) and F group (Fgp) cells, respectively (Benjamin and Winlow, 1981). The Egp cells (8-10 cells) are generally found on the dorsal surface but in some instances have been found to extend more ventrally across the anterior surface. Fgp cells (15-18 cells) are located on the lateral surface of the ganglion and extend ventrally. The numbers of neurons expressing the tetrapeptide exon varied in the two groups. Up to 10 cells expressed (five shown in Fig. $8 B$ ) the tetrapeptide exon in the more anterior (Egp) cells, whereas a maximum of six cells (one shown in Fig. 8E) occurred in the lateral-ventral group (Fgp). Thus, the Egp appears to consist mainly of tetrapeptide cells, whereas only a small proportion of the Fgp express the same exon. The dorsal/dorsal-anterior Egp cells described here are characterized by the strength of the hybridization signal that they produce to the tetrapeptide exon probe, which is stronger than any other cell group identified (Fig. $8 B$ ).

Two large (100-150 $\mu \mathrm{m}$ in diameter), ellipsoidal cells that characteristically exhibited a faint tetrapeptide signal are located just ventrally to the dorsal surface on the left posterior side of the ganglion (Fig. 3B). The position and morphological characteristics of these cells suggested that they might correspond to two identified giant neurons VD2 and VD3 (visceral-dorsal 2 and 3 ). 

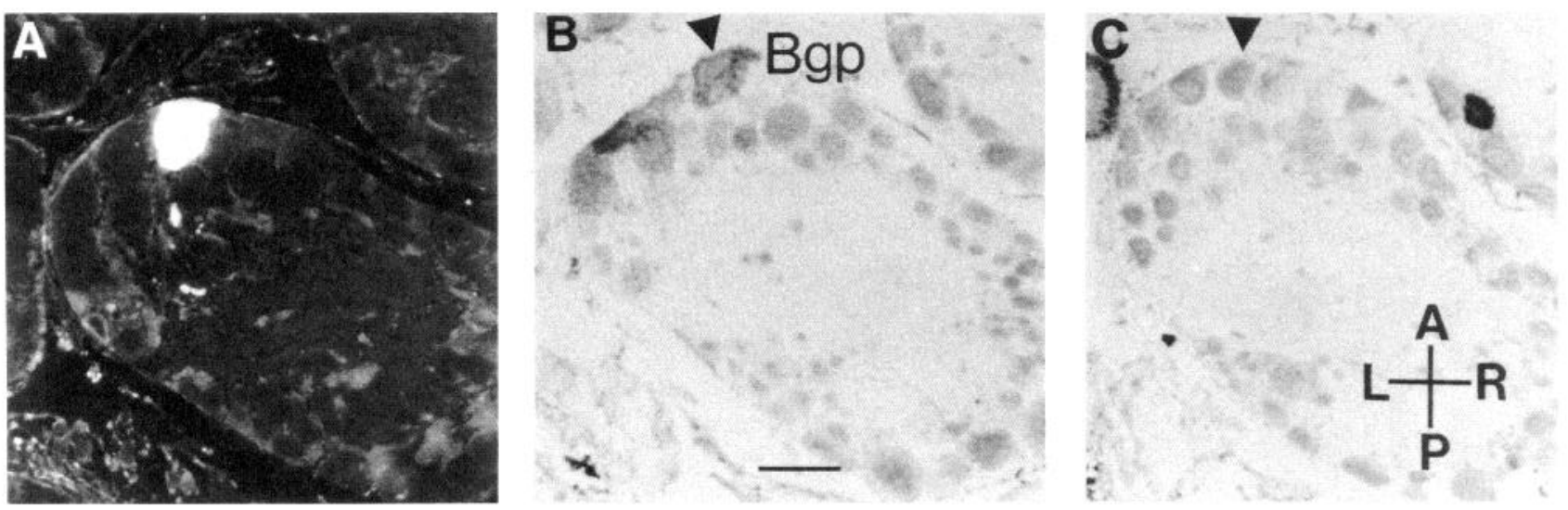

Figure 7. Identified Lucifer yellow-marked Bgp (B group) neuron $(A)$ of the right parietal ganglia that expresses the heptapeptide $(B)$ but not the tetrapeptide FMRFamide exon (C). Scale bar, $100 \mu \mathrm{m}$.

Finally there was a population of up to eight small- to medium-sized tetrapeptide-expressing cells scattered throughout the visceral ganglion (Table 1).

As well as the 30 tetrapeptide-expressing neurons in the visceral ganglion, a separate population of 26 heptapeptide-expressing cells occurs (Table 2). Some of these are scattered throughout the ganglion but the majority $(n=14$, lateral-ventral cells, Table 2) are located in a lateral position stretching from the dorsal to the ventral surface (Fig. $3 B, D$ ). They are a compact group of medium to large neurons (Fig. $8 D$ ) and appear to form the majority of the Fgp cells. The tetrapeptide cells described above are scattered among this much larger number of heptapeptide-expressing cells. On this analysis, a maximum of 14 of the Fgp are heptapeptide expressing and six tetrapeptide expressing. This is about the maximum number of electrophysiologically mapped Fgp cells $(n=18)$ reported by Benjamin and Winlow (1981). Confirmation that most of the Fgp cells expressed the heptapeptide exon came from dye marking electrophysiologically characterized Fgp cells. Heptapeptide but not tetrapeptide expression was seen in all four marked neurons (e.g., Fig. $8 D, E$ ). Two or three of the remaining heptapeptideexpressing cells (Fig. $3 \mathrm{~A}$ ) were in a location consistent with them being Egp cells. These would form a small minority of the cluster consisting mainly of tetrapeptide-expressing cells (Fig. $3 A$ ). This analysis was confirmed by dye marking eight Egp cells (e.g., Fig. $8 A, B)$. Seven of these expressed the tetrapeptide exon, none the heptapeptide exon, and one neither exon. Data reported elsewhere (Skingsley et al., 1993) showed that one of the heptapeptide-expressing cells located close to the Egp was an identified cell called the visceral white interneuron.

\section{Discussion}

\section{Comparison of in situ analysis with immunocytochemistry}

In 1982 Schot and Boer published an immunocytochemical study of the distribution of FMRFamide-related peptides in Lymnaea stagnalis (Schot and Boer, 1982). Using an antiserum raised to the common C-terminal Arg-Phe-amide moiety found on both heptapeptides and tetrapeptides, they observed immunoreactive material in all 11 ganglia as well as positively stained fibers in a number of peripheral organs (e.g., the heart, reproductive tract, and gut). Our in situ data in the CNS are consistent with this study, except we can now distinguish cells expressing the two classes of peptide.
A direct comparison between the immunocytochemical study and the in situ analysis presented here cannot be simply made as it should be borne in mind that the Schot and Boer study did not illustrate the expression of the peptides by way of the more detailed maps presented here or relate the maps to the level of identified neurons. They also found that the number of immunoreactive cells differed depending on fixation. However, comparison can be made between the maximum number of immunoreactive cells identified within each ganglion and the cells identified by in situ hybridization. This indicated that the numbers of cells identified in the buccal, cerebral, right parietal, and visceral ganglia agree well, whereas more cells are observed in the pleural, pedal, and left parietal ganglia by in situ hybridization than immunocytochemistry. Consequently, the total number of cells identified by in situ hybridization (341) is greater than those identified with the antibody (231). However, the positions, sizes, and grouping of many of the immunoreactive cells compare well with those described in the Schot and Boer study. One explanation for this is that not all the cells expressing the mRNA in the in situ analysis translate the message into the final peptide products.

\section{Differential splicing in FMRFamide systems}

The data discussed in this article emphasize the observation that the Lymnaea FMRFamide gene is differentially spliced in a wide variety of cells. Transcripts encoding FMRFamide-related peptides generally appear to be spliced. In Aplysia the pattern of splicing of the tetrapeptide encoding exon onto a hydrophobic leader sequence is similar to that observed in $\mathrm{Lym}$ naea (Schaefer et al., 1985), and it remains to be determined whether other exons of the same gene exist. The expression of the Drosophila gene has been analyzed by both immunocytochemistry (White et al., 1986; Chin et al., 1990) and in situ hybridization (Chin et al., 1990; O'Brien et al., 1991; Schneider et al., 1991), and has been shown to be expressed in $\sim 60$ cells within the nervous system. The possibility that the prohormone undergoes differential processing has been suggested from the study by Chin et al. (1990) whereby an antibody generated against a peptide spanning a potential proteolytic cleavage site within the precursor is shown to stain a unique set of cells. However, the specificity of this antibody to the FMRFamide precursor has yet to be conclusively shown, and thus the question of whether differential processing actually occurs remains unan- 

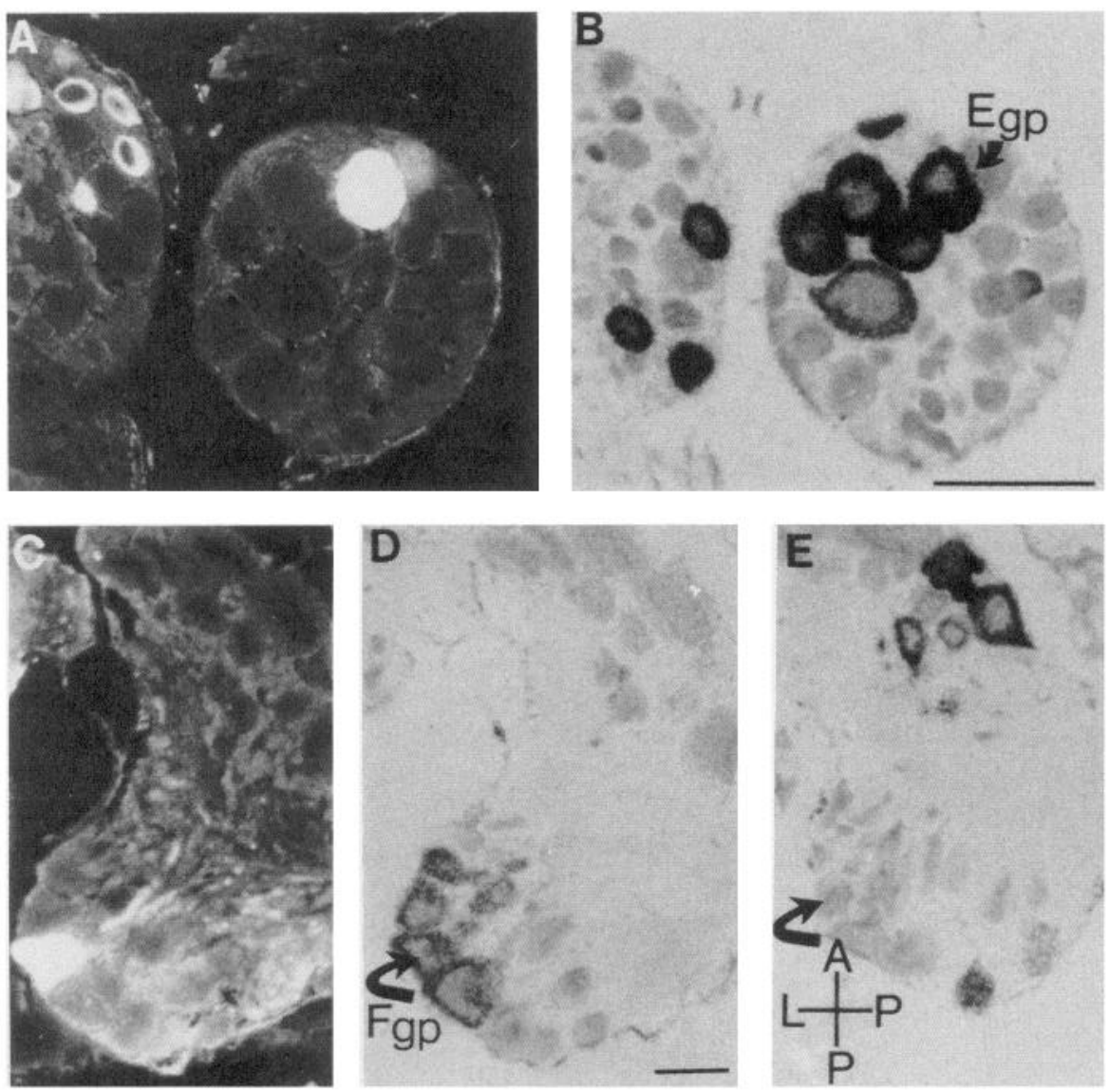

Figure 8. Identified neurons of the visceral ganglion Egp (E group) and Fgp (F group). $A$, Dye-filled Egp cell expresses the FMRFamide tetrapeptide exon $(B)$. $C$, Dye-filled Fgp cell, expressing the heptapeptide exon $(D)$ but not the tetrapeptide exon $(E)$. Scale bar, $100 \mu \mathrm{m}$.

swered. Thus, while the splicing strategy of the Drosophila gene appears simple, it may use mechanisms of posttranslational processing to generate diversity from its transcription unit, in a manner analogous to the vertebrate proopiomelanocortin prohormone. However, whether the prohormones derived from the spliced Lymnaea gene transcripts are also subject to differential processing has yet to be determined.

One significant similarity between the expression of the FMRFamide-related peptide encoding genes of Lymnaea and Drosophila is their widespread distribution throughout the nervous system, which suggests important physiological roles for FMRFamide-related peptides in both systems. The detection of axonal projections of the 60 Drosophila FMRFamide-immunoreactive central neurons has suggested that they are involved in a variety of physiological processes (Chin et al., 1990) and include neurosecretory cells that project to release sites in the periphery and interneurons whose processes are confined to the CNS (Schneider and Taghert, 1990). The results reported here show that the Lymnaea gene is similarly expressed in a wide variety of cell types, and the 341 cells expressing the gene constitute about $1.5 \%$ of the central neuronal population (estimated to be 25,000 by Benjamin et al., 1985).

Neurons expressing the tetrapeptide exon are far more abundant than those expressing the heptapeptide exon, the ratio being approximately $5: 1$. This was unexpected since Ebberink et al. (1987) had reported that FMRFamide itself accounts for about $20 \%$ of the total FMRFamide-like immunoreactivity in an extract of the CNS. The two other peptides GDPFLRFamide and SDPFLRFamide contributed the other $80 \%$ of the immuno- reactivity (Ebberink et al., 1987). The relative expression of the exons encoding these peptides is the exact reverse of this estimate ( $20 \%$ hepta-, $80 \%$ tetrapeptide). However, transcript levels may not always correlate with peptide levels due to differences in the stability or the translational efficiency of particular transcripts or differences in posttranslational processing.

\section{Different levels of expression of $m R N A$}

One striking observation from Table 1 is that steady state levels of cytoplasmic RNA vary greatly between cells in different ganglia and also within the same ganglia; for example, the cerebral ganglia contain the highest expressing levels of FMRFamide transcript in the dorsal lobe whereas the signal in the medial posterior group is barely detectable. The consistency in signal strength between the same cell in different preparations suggests that regulation is at the level of genetic control. It is interesting that cells within a particular cluster, for example, those identified as being in the Egp or the Fgp, all seem to contain similar amounts of hybridizing mRNA. The steady state level is clearly dependent upon overall balance of rate of synthesis and degradation. Levels of expression in identified groups of cells may be a consequence of a common cell lineage for that particular group that, for example, determines the level of transcription. Similarly, the RNA splicing pathway probably depends upon cell lineage, although it is unlikely considering the distribution of FMRFamide- and GDP/SPDFLRFamide-expressing cclls, that all cells that splice in one particular pathway have the same developmental history, and therefore the switch between splicing pathways probably occurred at different times in different 
cells. Analysis of the transcriptional promoter for the FMRFamide gene and developmental studies on the expression of spliced RNA will show how the system is regulated.

\section{Analysis of identified neuronal systems}

A most striking feature of the expression of the tetrapeptide and heptapeptide exons in Lymnaea is its widespread occurrence in a number of behaviorally important networks. Dye marking allowed the expression to be correlated with individually identified neurons. Other prominent Lymnaea peptides occur in one specific system and must be more limited in function (egg laying hormone and the MIPS (molluscan insulin-like peptides) system, reviewed in Geraerts et al., 1991). Most widespread is the tetrapeptide exon that occurs in neurons of the whole body withdrawal motoneuronal system, penis control system, and Egp neurons, containing a pair of cells of the heart motoneuronal control system. Motoneurons involved in withdrawal of the body into the shell following sensory stimulation occur in all nine ganglia of the Lymnaea ganglionic ring (Ferguson and Benjamin, 1991a). Prominent among these cells are two bilaterally symmetrical clusters of cells, called the cerebral A cluster, which express the FMRFamide exon. Most of the cells in the posterior part of the A cluster are motoneurons of the DLM, but there is also a pair of bilaterally symmetrical columellar muscle motoneurons in the same cluster. These correspond to motoneuronal populations of lightly tetrapeptide exon-expressing cells and the numbers of cells on each side located by the in situ probe corresponded well with those revealed by the previous electrophysiological studics (Ferguson and Benjamin, 1991a). The presence of the same exon in other members of the withdrawal response motoneuronal network was also shown by dye marking the single left parietal ganglion neuron or locating the pedal $\mathrm{N}$-cell cluster neurons close to the origin of the pedalcerebral and pedal-pleural connectives by in situ mapping. Both these cell types are motoneurons of the DLM. Heptapeptideexpressing neurons either are absent from the ganglia where motoneurons of the withdrawal response network occur (pedal, cerebral ganglia) or are found in different locations (left parietal ganglion).

The consistent presence of the tetrapeptide exon in different motoneurons of the whole body withdrawal system suggested that FMRFamide/FLRFamide and other peptides present on the same exon are transmitters or cotransmitters. We do not have any physiological evidence for this in Lymnaea, but it is interesting that the related $\mathrm{C} 3$ tentacle withdrawal motoneuron of Helix also appears to contain FMRFamide (Berwick et al., 1990) as well as ACh (Xu et al., 1991), and FMRFamide can mimic the synaptic actions of C3 (Cottrell et al., 1983). The cerebral C3 neuron of Helix may be homologous with withdrawal response neurons in Lymnaea, although no specific tentacle withdrawal response neurons were so far found in this latter species.

The penial complex of Lymnaea (a hermaphrodite snail) consists of preputium, penis, and attached muscles. The nerve innervating the penis originates from the right cerebral ganglion. The in situ data show approximately 60-80 cells strongly hybridizing with the tetrapeptide exon probe, but none in the same region with the heptapeptide probe, suggesting that the neural network involved in controlling the penis may thus also be a system associated with FMRFamide expression.

The presence of tetrapeptide- and heptapeptide-expressing neurons in these three very prominent clusters of cells of the right parietal and visceral ganglia confirms the previous immunocytochemical and radioimmunoassay analysis, which shows the presence of FMRFamide-like peptides (Benjamin et al., 1988). These readily identifiable neurons should prove useful models for the study of the physiological role of neurons expressing both classes of cxon, the Egp for the tetrapeptides and the Bgp and Fgp for the heptapeptides.

All the most prominent Bgp and Fgp cells identified by dye marking were heptapeptide expressing and so are readily available for further pharmacological and behavioral studies. A single identifiable cell, the visceral white interneuron, also expresses the heptapeptide exon (Skingsley et al., 1993).

The Egp (8-10 cells) contains a pair of heart excitatory motoneurons, the $E_{\text {he }}$ cells (Buckett et al., 1990b), which we conclude must express the tetrapeptide exon. These were not specifically targeted but they were almost certainly dye marked in the present study. Given the predominance of tetrapeptide expression in the Egp (it contains one heptapeptide-expressing cell) shown by general in situ mapping and the results of application of the tetrapeptide exon probe to dye-marked cells (seven out of eight Egp dye-marked cells expressed the tetrapeptide exon), the $E_{h e}$ cells must express the tetrapeptide exon.

The presence of the tetrapeptide exon in the $E_{h e}$ cells is consistent with physiological evidence that showed that the $E_{h e}$ excitatory effects on the heart were most closely mimicked by low concentrations of FMRFamide or FLRFamide. The Lymnaea tetrapeptides are also the most prominent type of FMRFamide-related peptides present in the heart tissue (Buckett et al., 1990a). Specific ion channels (voltage-insensitive $\mathrm{Ca}^{2+}$ ) were also opened by FMRFamide or FLRFamide in isolated Lymnaea ventricular cells in a highly specific manner (Brezden et al., 1991).

\section{References}

Benjamin PR, Elliot CJH (1989) Snail feeding oscillator: the central pattern generator and its control by modulatory interneurons. In: Cellular and neuronal oscillators (Jacklet J, ed), pp 173-214. New York: Dekker.

Benjamin PR, Ings C (1972) Golgi-Cox studies on the central nervous system of a gastropod mollusc. Z Zellforsch 128:564-582.

Benjamin PR, Winlow W (1981) The distribution of three wide-acting synaptic inputs to identified neurons in the isolated brain of Lymnaea stagnalis (L). Comp Biochem Physiol [A] 70:293-307.

Benjamin PR, Slade CT, Soffe ST (1980) The morphology or neurosecretory neurons in the pond snail, Lymnaea stagnalis, by the injection of Procion yellow and horseradish peroxidase. Philos Trans R Soc London [Biol] 290:449-478.

Benjamin PR, Elliott CJH, Ferguson GP (1985) Neural network analysis in the snail brain. In: Model neural networks of bchavior (Sclverston A, ed), pp 87-108. New York: Plenum.

Benjamin PR, Buckett KH, Peters M (1988) Neurons containing FMRFamide-like peptides in the model invertebrate system $\mathrm{Lym}_{\text {- }}$ naea. Symp Biol Hung 3:247-259.

Bewick GS, Price DA, Cottrell GA (1990) The fast response mediated by the $\mathrm{C} 3$ motoneuron of Helix is not attributable to the contained FMRFamide. J Exp Biol 148:201-219.

Brezden B, Benjamin PR, Gardner DR (1991) FMRFamide activates a divalent cation-conducting channel in heart muscle cells of the snail Lymnaea stagnalis. J Physiol (Lond) 443:727-739.

Buckett KH, Dockray GJ, Osborne NN, Benjamin PR (1990a) Pharmacology of the myogenic heart of the pond snail Lymnaea stagnalis. J Neurophysiol 63:1413-1425.

Buckett KH, Pcters M, Dockray GJ, van Minnen J, Benjamin PR (1990b) Regulation of heartbeat in Lymnaea by motoneurons containing FMRFamide-like peptides. J Neurophysiol 63:1426-1435.

Burke JF, Kellett E, de Lange B, Santama N, Saunders S, Benjamin PR (1992) FMRFamide gene expression. Methods Neurosci 9:64-78. 
Chin AC, Reynolds ER, Scheller RH (1990) Organization and expression of the Drosophila FMRFamide-related prohormone genc. DNA Cell Biol 9:263-271.

Cottrell GA, Davies NW (1987) Multiple receptor sites for a molluscan peptide (FMRFamide) and related peptides of Helix. J Physiol (Lond) 382:51-68.

Cottrell GA, Schot LPC, Dockray GJ (1983) Identification and probable role of a single neuron containing the peptide FMRFamide. Nature 304:638-640.

Ebberink RHM, Price DA, Van Loenhout H, Doble KD, Riehm JP, Geraerts WPM, Greenberg MJ (1987) The brain of Lymnaea contains a family of FMRFamide-like peptides. Peptides 8:515-522.

Elliott CJH, Benjamin PR (1985) Interactions of pattern gencrating interneurons controlling feeding in Lymnaea stagnalis. J Neurophysiol 54:1396-1411.

Ferguson GP, Benjamin PR (1991a) The whole-body withdrawal response of Lymnaea stagnalis. I. Identification of central motoneurons and muscles. J Exp Biol 158:63-95.

Ferguson GP, Benjamin PR (1991b) The whole-body withdrawal response of Lymnaea stagnalis. II. Activation of central motoneurons and muscles by sensory input. J Exp Biol 158:97-116.

Geraerts WPM, Smit AB, Li KW, Vreugdenhil E, van Heerikhuizen $H$ (1991) Neuropeptide gene families that control reproductive behaviour and growth in molluscs. Curr Aspects Neurosci 3:255-303.

Haydon PG, Winlow W (1982) Multipolar neurons of Lymnaea stagnalis. I. Multiple spike initiation sites and propagation failure allows compartmentalization. J Comp Physiol 147:503-510.

Linacre A, Kellett E, Saunders SE, Bright K, Benjamin PR, Burke JF (1990) Cardioactive neuropeptide Phe-Met-Arg-Phe-NH (FMRFamide) and novel related peptides are encoded in multiple copies by a single gene in the snail Lymnaea stagnalis. J Neurosci $10: 412-419$

Nambu JR, Murphy-Erdosh C, Andrews PC, Gottfried J, Feistner CJ, Scheller RH (1988) Isolation and characterization of a Drosophila neuropeptide. Neuron 1:55-61.

O'Brien MA, Schneider LE, Taghert PH (1991) In situ hybridization analysis of the FMRFamide neuropeptide gene in Drosophila. II Constancy in the cellular pattern of expressing during metamorphosis. J Comp Neurol 304:623-638.

Price DA (1986) Evolution of a molluscan cardioregulatory neuropeptide. Am Zool 26:1007-1015.

Sambrook J, Fritsch EF, Maniatis T (1989) Molecular cloning: a laboratory manual, 2d ed. Cold Spring Harbor, NY: Cold Spring Harbor Laboratory.

Saunders SE, Bright K, Kellett E, Benjamin PR, Burke JF (1991) Neu- ropeptides GDPFLRFamide and SDPFLRFamide are encoded by an exon $3^{\prime}$ to FMRFamide in the snail Lymnaea stagnalis. J Neurosci 11:740-745.

Saunders SE, Kellett E, Bright K, Benjamin PR, Burke JF (1992) Cellspecific alternate RNA splicing of an FMRFamide gene transcript in the brain. J Neurosci 12:1033-1039.

Schaefer M, Picciotto MR, Kreiner T, Kaldany R-R, Taussig R, Scheller RH (1985) Aplysia neurons express a gene encoding multiple FMRFamide neuropeptides. Cell 41:457-467.

Schneider LE, Taghert PH (1988) Isolation and characterization of a Drosophila gene that encodes multiple neuropeptides related to PheMet-Arg-Phe- $\mathrm{NH}_{2}$ (FMRFamide). Proc Natl Acad Sci USA 85:19931997.

Schneider LE, O’Brien MA, Taghert PH (1991) In situ hybridization analysis of the FMRFamide neuropeptide gene in Drosophila. I. Restricted expression in embryonic and larval stages. I Comp Neurol 304:608-622.

Schot LPC, Boer HH (1982) Immunocytochemical demonstrations of peptidergic cclls in the pond snail Lymnaea stagnalis with an antiserum to the molluscan cardioactive peptide FMRFamide. Cell Tissue Res 225:347-354.

Skingsley DR, Bright K, Santama N, Van Minnen J, Brierley MJ, Burke JF, Benjamin PR (1993) A molecularly-defined cardio-respiratory, intemeuron expressing SDPFLRFamide/GDPFLRFamide in the snail Lymnaea: monosynaptic connections and pharmacology. J Neurophysiol, in press.

Slade CT, Mills J, Winlow W (1981) The neural organization of the paired pedal ganglia of Lymnaea stagnalis (L.). Comp Biochem Physiol [C] 69:789-803.

Van Duivenboden YA (1984) Sexual behaviour of the hermaphrodite snail Lymnaea stagnalis. PhD thesis, Vrije Universiteit, Amsterdam.

Weiss S, Goldberg JI, Chochan KS, Stell WK, Drummond GI, Lukowiak $\mathrm{K}$ (1984) Evidence for FMRFamide as a transmitter in the gill of Aplysia californica. J Neurosci 4:1994-2000.

White K, Hurteau T, Punsal P (1986) Neuropeptide-FMRFamidelike immunoreactivity in Drosophila: development and distribution. J Comp Neurol 247:430-438.

Winlow W, Benjamin PR (1976) Neuronal mapping of the brain of the pond snail Lymnaed stagnalis L. In: Neurobiology of invertebrates. Gastropoda brain (Salanki J, ed), pp 41-61. Budapest: Akademiai Kiado.

Xu GP, Bewick GS, Cottrell GA (1989) The Helix C3 motoneuron contains Ach and FMRFamide. Comp Biochem Physiol [C] 94:321325 . 